\title{
湍流Rayleigh-Bénard热对流温度剖面中对数律 研究
}

\author{
黄茂静, 包芸* \\ 中山大学应用力学与工程系, 广州 510275 \\ *联系人, E-mail: stsby@mail.sysu.edu.cn
}

收稿日期: 2016-10-11; 接受日期: 2016-12-13; 网络出版日期: 2017-02-28

国家自然科学基金(编号: 11372362,11452002)、中央高校基本科研业务费专项资金(编号: 14lgjc02)和国家自然科学基金委员会-广东省人 民政府联合基金(第二期)超级计算科学应用研究专项(编号：nsfc2015_570)资助

摘要＼cjkstart本文采用湍流热对流的并行直接数值模拟(Parallel Direct Method of Direct Numerical Simulation, PDM-DNS), 计算了系列 $R a$ 数的二维方腔Rayleigh-Bénard热对流. 选取典型 $R a=10^{10}, P r=4.3$, 讨论了流动平均场 的近底板区域温度分布. 温度边界层沿横向可分为三个区域: 羽流发射区、冲击区和大尺度环流剪切区. 在羽 流发射区温度剖面存在对数律, 冲击区和大尺度环流剪切区没有明显的对数律特征. 横向平均得到的温度剖 面也存在对数律. 研究系列 $R a$ 数的横向平均温度剖面, 得到温度变化满足 $A \times \log (y)+B$ 的关系, 温度剖面对数律 振幅 $-A$ 和 $R a$ 数呈现标度关系 $-A \sim R a^{-0.145}$, 与实验中发现的关系基本一致.

关键词 Rayleigh-Bénard热对流, 湍流, 温度剖面对数律, PDM-DNS

PACS: $47.27 . T e$, 47.20.Bp, 47.11.-j

\section{1 引言}

热对流现象广泛存在于天体、太阳、地球地幔、 大气环流和海洋环流等自然界中, 以及核反应堆堆芯 冷却系统、化工产品生产和电子元件设计等工程应 用领域中. 湍流热对流物理和流动特性的研究可以深 化人类对自然界中热对流现象的认识, 也可以对解决 工程中的传热问题给出指导. Rayleigh-Bénard (RB)对 流系统模型是湍流热对流研究中几个最简单的物理 模型之一 ${ }^{[1]}$.
在湍流RB对流系统中, 上顶板和下底板附近都存 在很薄的速度和温度边界层 ${ }^{[2]}$. 对于目前大多数在研 究的高 $R a$ 数湍流热对流系统, 边界层虽然有波动, 但 还是层流的 ${ }^{[3,4]}$. 有关湍流热对流的理论研究, 预测在 极高 $R a$ 数下, 温度边界层将会变为湍流并且温度的分 布将会贯穿整个腔体, 此时在平均温度场中温度分布 随离底板的垂直距离呈现对数变化 ${ }^{[5]}$, 但在现有可实 现的高 $R a$ 数湍流热对流实验中发现了温度分布随距 离呈对数变化. 在DNS模拟数据中也发现温度分布同 样具有对数关系 ${ }^{[2]}$.

引用格式: 黄茂静, 包芸. 湍流Rayleigh-Bénard热对流温度剖面中对数律研究. 中国科学: 物理学力学 天文学, 2017, 47: 064701 2017, 47: 064701, doi: 10.1360/SSPMA2016-00427 
Ahlers等人 ${ }^{[6]}$ 认为 $R B$ 热对流系统中的对数温度分 布, 类似于剪切流系统中流向速度的对数剖面. 在剪 切流系统中, 速度对数剖面是由于近边壁剪切不稳定 产生的, 而在湍流RB热对流系统中, 温度剖面对沿平 板的剪切依赖不明显, 这可能和羽流的存在以及羽流 的空间分布有关. 在二维大宽高比侧壁周期条件的热 对流DNS计算中, 可以清晰地看到多个横向排列的大 尺度环流及导致的羽流运动, 由此可将底板边界层沿 横向分为三个区域: 羽流发射区、冲击区和大尺度环 流剪切区, 同时发现在羽流发射区, 温度剖面具有对 数律, 而在冲击区和大尺度环流剪切区, 温度剖面的 对数率不明显 ${ }^{[7]}$. 在 $P r=0.78, \Gamma=0.5$ 的圆柱型对流槽的 湍流热对流实验中也发现了温度剖面具有对数律, 而 且近边壁处的对数律振幅最大, 越到中间位置振幅越 小, 表明垂向温度剖面对数律受边壁的影响 ${ }^{[2]}$.

本文采用DNS模拟计算了二维方腔热对流系统, 其中 $P r=4.3,10^{9} \leq R a \leq 10^{12}$. 选取 $R a=10^{10}$, 研究温度边界 层分布和特性, 以及局部温度剖面和横向平均温度剖 面的特性, 并研究了横向平均的温度剖面对数律振幅 随 $R a$ 数的变化规律.

\section{DNS 数值计算及结果讨论}

在Oberbeck-Boussinesq近似下, 使用 $H,(\beta g H \Delta \theta)^{1 / 2}$, $H(\beta g H \Delta \theta)^{-1 / 2}$, 和 $\Delta \theta$ 分别作为单位长度、单位速度、单 位时间和单位温度, 对控制方程无量纲化. 无量纲化 的热对流方程为

$$
\left\{\begin{array}{l}
\nabla \cdot \boldsymbol{u}=0, \\
\frac{\partial \boldsymbol{u}}{\partial t}+(\boldsymbol{u} \cdot \nabla) \boldsymbol{u}=-\nabla p+\frac{1}{\sqrt{R a / P r}} \nabla^{2} \boldsymbol{u}+\theta \boldsymbol{k}, \\
\frac{\partial \theta}{\partial t}+(\boldsymbol{u} \cdot \nabla) \theta=\frac{1}{\sqrt{R a \cdot P r}} \nabla^{2} \theta,
\end{array}\right.
$$

其中, $\boldsymbol{u}$ 为无量纲速度矢量, $\theta$ 为无量纲温度, $\boldsymbol{k}$ 为单位 垂向矢量, $p$ 为压力. 无量纲参数 $R a=\left(\beta g \Delta \theta H^{3}\right) / \kappa v$ 为瑞 利数, 是浮力驱动力与阻碍运动的力的比值, $P r=v / \kappa$ 为 普朗特数, 决定系统中黏性边界层和温度边界层的比 值, $\Gamma=W / H$ 反映了对流系统的几何尺寸. $\beta$ 为热膨胀系 数, $g$ 为重力加速度, $\Delta \theta$ 为上下壁面温差, $H$ 为系统装置 的高度, $W$ 为系统装置的宽度, $v$ 为运动黏性系数, $\kappa$ 为 热扩散率. 所有固壁面均使用无滑移速度边界条件, 在侧壁面使用绝热边界条件, 而在上底板和下底板设
置恒温边界条件, 分别为 -0.5 和 0.5 .

不可压流动的湍流RB热对流DNS数值模拟计算 采用了投影法, 其中压力泊松方程采用了并行直接求 解方法(PDM-DNS $)^{[8]}$. 用快速傅里叶变换(Fast Fourier Transform, FFT)解耦泊松方程成系列三对角方程, 然 后求解三对角方程, 通过FFT逆变换求解压力泊松方 程. 使用“天河二号”超级计算机, 对湍流RB热对流系 统系列 $R a$ 数进行了高效并行DNS数值模拟计算. 获取 时间平均场数据, 分析研究湍流RB热对流的传热特性 和温度剖面对数律特性.

$R B$ 热对流系统研究的一个核心问题是, 由热浮 力引起的湍流流动传输热量的能力, 用系统整体传热 Nusselt数 $(N u)$ 表示. 无量纲的 $N u$ 数计算公式如下:

$N u=\sqrt{R a \cdot \operatorname{Pr}}\left\langle u_{z} \theta\right\rangle_{A}-\langle\partial \theta / \partial z\rangle_{A}$,

其中 $\langle\cdots\rangle_{A}$ 表示横向平均.

图 1 给出了本文二维数值模拟计算的 $N u$ 数和其 他研究者的结果对比. 红色实心圆圈为 $P r=4.3$ 的二维 数值模拟结果, 黑色空心三角为Van der Poel等人 ${ }^{[9]}$ $P r=4.38$ 的二维数值模拟结果. 从 $N u / R a^{0.3}$ 与 $R a$ 的关 系图中可以看到, $R a<10^{10}$ 时数据结果稍微向上倾斜, $R a \geq 10^{10}$ 时数据结果稍微向下倾斜, 但总体来说, 数据 结果基本在 0.1 附近. 发现本文计算的 $N u$ 数和 Van der Poel等人 ${ }^{[9]}$ 计算的 $N u$ 数基本一致, 由此可以表明本文 的计算结果是合理可靠的.

从图 2 可以看到, 当 $R a=10^{9}$ 时, 大尺度环流近似栯

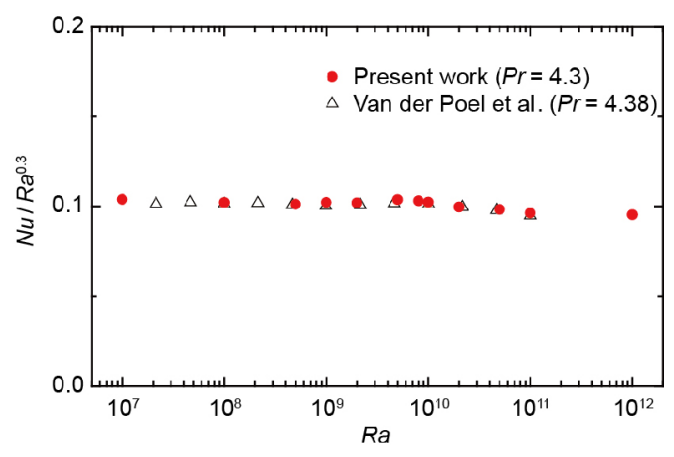

图 1 (网络版彩图) $N u / R a^{0.3}$ 与 $R a$ 的关系图. 红色实心圆圈表 示本文 $P r=4.3$ 的二维数值模拟结果, 黑色空心三角表示 $\operatorname{Van}$ der Poel等人 ${ }^{[9]}$ 的二维数值模拟结果, 其中 $P r=4.38$

Figure 1 (Color online) $N u / R a^{0.3}$ versus $R a$ scaling for $P r=4.3$. The current simulation result for two-dimension RB is indicated by the red dot. The two-dimension numerical data from Van der Poel et al. [9] $(P r=4.38)$ are indicated by the open black triangles. 


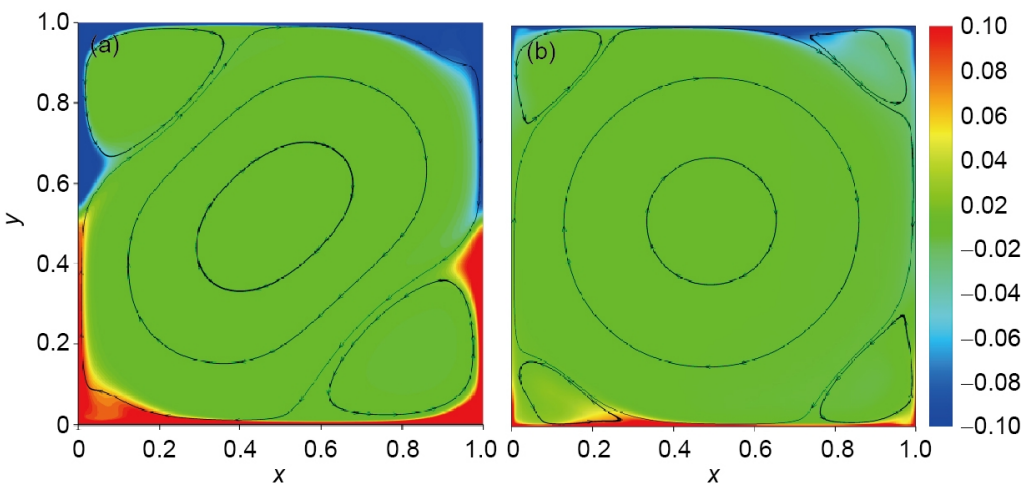

图 2 (网络版彩图)平均温度场图, 颜色代表温度大小, 箭头方向表示流动方向. (a) $R a=10^{9}$; (b) $R a=10^{10}$

Figure 2 (Color online) The time-averaged temperature fields for two values of $R a$. (a) $R a=10^{9}$; (b) $R a=10^{10}$. The temperature is coded in color, and the arrow indicates the flow direction.

圆形, 在左上角和右下角存在两个角浴. 大尺度环流 和角浴在近底板处的交点在 $x=0.6$ 附近. 当 $R a=10^{10}$ 时, 大尺度环流近似呈圆形, 方腔的四个角落都存在尺寸 大小基本一致的角浴. 大尺度环流和角浴在近底板处 的交点在 $x=0.3$ 和 $x=0.7$ 附近. 随着 $R a$ 数的增加, 大尺度 环流变圆, 角浴变小.

\section{3 平均场温度剖面特性}

选取典型算例 $R a=10^{10}$ 的平均温度场, 研究了近底 板处的温度分布及特性、局部温度剖面和横向平均 温度剖面的特性以及横向平均温度剖面的对数律系 数 $A$ 与 $R a$ 数的关系.

\section{1 近底板处的平均温度场}

Van der Poel等人 ${ }^{[7]}$ 将边界层沿横向分为三个区域, 即羽流发射区、冲击区和大尺度环流剪切区. 大尺度 环流剪切区在发射区和冲击区之间. 在发射区和冲击 区, 速度主要是垂向的, 而在剪切区, 速度是水平方向 的. 这些区域存在于上下板, 只是在水平位置上不同, 顶板附近边界的羽流发射区是底板附近边界的冲击 区, 反之亦然. 图3给出了 $R a=10^{10}$ 近底板处的平均温 度场.

从图3中二维方腔流动的近底板温度分布和流线 可以看到, 在 $x<0.4$ 和 $x>0.9$ 处有很厚的高温层存在. 发 射区为 $0.2<x<0.4$, 冲击区为 $0.7<x<0.8$, 大尺度环流剪 切区为 $0.4<x<0.7$. 对于区域 $x<0.2$ 和 $x>0.8$, 温度分布受 角浴的影响, 在近侧壁处, 高温层比较厚.

Ahlers等人 ${ }^{[2]}$ 对实验和数值模拟结果进行研究, 其

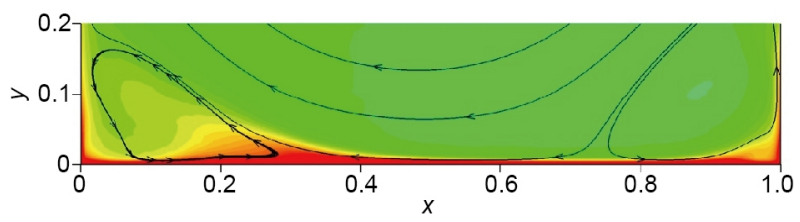

图 3 (网络版彩图) $R a=10^{10}$ 的平均温度场近底板的温度场 图

Figure 3 (Color online) Mean temperature fields near the bottom of the sample for $R a=10^{10}$.

中实验中的参数为 $\Gamma=0.5, P r=0.8,4 \times 10^{12}<R a<10^{15}$, DNS 中的参数为 $\Gamma=0.5, P r=0.7, R a=2 \times 10^{12}, 2 \times 10^{11}, 2 \times 10^{10}$, 发 现实验和数值模拟的温度剖面都存在对数律. 对于圆 柱型对流槽, 随着从边壁到腔体中部, 对数律振幅变 小. 温度剖面对数律不仅受边壁的影响, 也受羽流发 射区的影响。

\section{2 温度剖面中的对数律关系}

研究湍流 $\mathrm{RB}$ 热对流温度剖面特性, 在极高 $R a$ 数下, Grossmann和 Lohse ${ }^{[10]}$ 提出了两层模型. 对于 温度剖面, 两层模型中有对数项, 引入对数律关系 $<\theta>_{\mathrm{t}}=A \times \log (y)+B$, 其中 $y$ 是离下底板或上顶板的垂直距 离. 由Grossmann等人提出的模型, 加入更小的参数, 得到高 $R a$ 情况下的 $\mathrm{RB}$ 热对流中温度剖面对数律系数 $A$ 和常数 $B$ 的表达式. 系数 $A$ 为负值, 取 $-A$ 作为温度剖 面对数律振幅. 对于不同的横向位置, 发现局部温度 剖面对数律振幅的最大值出现在羽流集中区域, 表明 上升羽流和温度剖面对数律的振幅相关. 选取三个典 型的横向位置进行研究, 羽流发射区 $x=0.3$ 、冲击区 $x=0.7$ 和大尺度环流剪切区 $x=0.5$, 得到各自的温度剖 面, 同时也给出了横向平均的温度剖面, 如图4所示. 

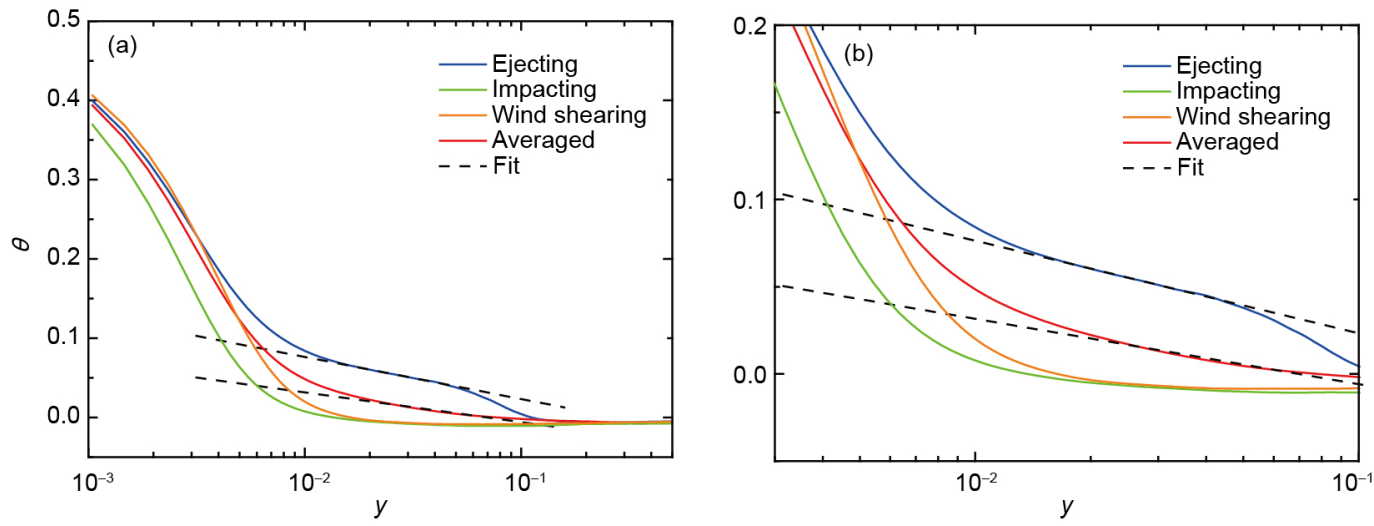

图 4 (网络版彩图)(a) 边界层三个区域和横向平均的平均场温度剖面; (b) 放大后的平均场温度剖面. 蓝色实线表示发射区 $x=0.3$ 处的温度剖面, 绿色实线表示冲击区 $x=0.7$ 处的温度剖面, 橙色实线表示大尺度环流剪切区 $x=0.5$ 处的温度剖面, 红色实 线为横向平均的温度剖面. 黑色虚线表示相应的温度剖面的对数拟合线.

Figure 4 (Color online) (a) Mean temperature profiles for three boundary layer regions and horizontally averaged; (b) the enlarged portion of the mean temperature profiles. The mean temperature profiles for ejecting $(x=0.3)$ and impacting $(x=0.7)$ and wind shearing region $(x=0.5)$ and horizontally averaged are indicated by blue, green, yellow and red line, respectively. The black dashed lines are the logarithmic fits to the corresponding profile.

图4(a)分别给出了 $R a=10^{10}$ 时三个区域各自的温度 剖面以及横向平均温度剖面. 蓝色实线表示发射区 $x=0.3$ 处的温度剖面, 绿色实线表示冲击区 $x=0.7$ 处的 温度剖面, 橙色实线表示大尺度环流剪切区 $x=0.5$ 处的 温度剖面,红色实线为横向平均的温度剖面. 从图4(b) 中可以看到, 在发射区存在温度剖面对数律, 冲击区 和大尺度环流剪切区的温度剖面都没有明显的对数 特征. 横向平均得到的温度剖面也存在对数律. 在 半对数坐标下, 羽流发射区的温度剖面对数律区域 为 $10^{-2}<y<5 \times 10^{-2}$, 横向平均的温度剖面对数律区域为 $2 \times 10^{-2}<y<8 \times 10^{-2}$.

研究不同 $R a$ 数下温度剖面中的对数律关系. 选取 $P r=4.3, R a=10^{9}, 10^{10}, 10^{11}$ 和 $10^{12}$ 四个典型算例, 讨论温 度剖面对数律区域和温度剖面对数律振幅 $-A$ 随 $R a$ 数 的变化.

图5给出了半对数坐标下四个典型 $R a$ 数横向平均 的温度关于垂向位置 $y$ 的关系图. 绿色实线表示 $R a=10^{9}$, 紫色实线表示 $R a=10^{10}$, 蓝色实线表示 $R a=10^{11}$, 红色实 线表示 $R a=10^{12}$. 从图 5 可以看到, $R a$ 数越大, 温度剖面 越靠近底板. 发现 $8 \times 10^{-3}<y<2 \times 10^{-1}$ 的范围内有对数律 区域. 为了能看得更加清楚, 图 5 中的插图给出了平移 后的温度剖面图, 黑色虚线为各自温度剖面的对数拟 合线. 当 $R a=10^{11}$ 时, 温度剖面向上平移 0.05 , 当 $R a=10^{10}$ 时, 温度剖面向上平移 0.1 , 当 $R a=10^{9}$ 时, 温度剖面向上 平移 0.15. 可以看到, 随着瑞利数的增加, 温度剖面对

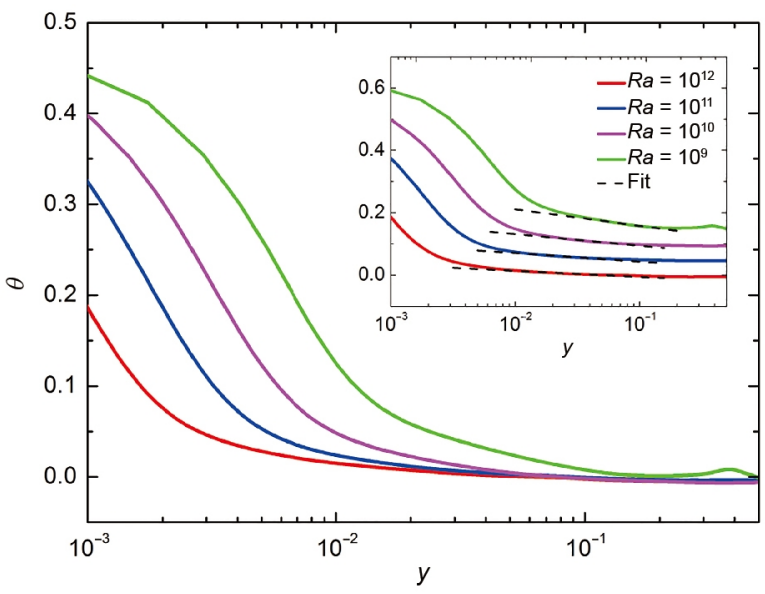

图 5 (网络版彩图)横向平均的平均场温度 $\theta$ 和垂向位置 $y$ 的关系. 绿色实线表示 $R a=10^{9}$, 紫色实线表示 $R a=10^{10}$, 蓝色 实线表示 $R a=10^{11}$, 红色实线表示 $R a=10^{12}$. 插图为平移后的 温度剖面图,黑色虚线为各自温度剖面的对数拟合线.

Figure 5 (Color online) The horizontally averaged temperature $\theta$ as a function of $y$ for four values of $R a, R a=10^{9}$ (green line), $R a=10^{10}$ (purple line), $R a=10^{11}$ (blue line), $R a=10^{12}$ (red line). For clarity, the profiles in the inset have been shifted vertically. The black dashed line represents the logarithmic fits to the corresponding temperature profiles.

数律区域变宽, 温度剖面对数律区域越来越靠近底板, 温度剖面对数律振幅 $-A$ 变小.

\section{3 对数律振幅 $-A$ 与 $R a$ 数的关系}

实验和DNS模拟研究都发现平均场温度剖面存 在对数律, 温度剖面对数律区域从边界层延伸到腔体 
的湍流区. 对于 $P r=0.78, \Gamma=0.5$ 的圆柱型对流槽, Ahlers 等人 ${ }^{[2]}$ 发现温度剖面对数律振幅 $-A$ 与 $R a$ 数的关系近 似为 $-A \sim R a^{-0.12}$. Grossmann和Lohse ${ }^{[10]}$ 提出的两层理论 模型预测了温度剖面对数律振幅 $-A$ 和 $R a$ 数的关系.

对于不同的 $R a$ 数, 对横向平均的温度剖面进行对 数拟合, 得到温度剖面对数律振幅 $-A$. 温度剖面对数 律振幅 $-A$ 与 $R a$ 的关系为 $-A \sim R a^{-\eta}$, 如图6所示.

从图6可以看到, 随着 $R a$ 数的增加, 对数律振幅 $-A$ 变小. Ahlers等人 ${ }^{[6]}$ 对 $P r=0.8, \Gamma=0.5$ 的圆柱型对流槽进 行实验研究发现, 当 $6 \times 10^{11} \leq R a \leq 10^{13}$ 时, 对数律振幅 $-A$ 和 $R a$ 的关系为 $\eta=0.125$, 当 $7 \times 10^{14} \leq R a \leq 1.1 \times 10^{15}$ 时, 对数 律振幅 $-A$ 和 $R a$ 的关系为 $\eta=0.176$, 其中对数律振幅 $-A$ 是由径向位置 $(R-r) / L=0.0045$ 处的温度剖面得到. 对温

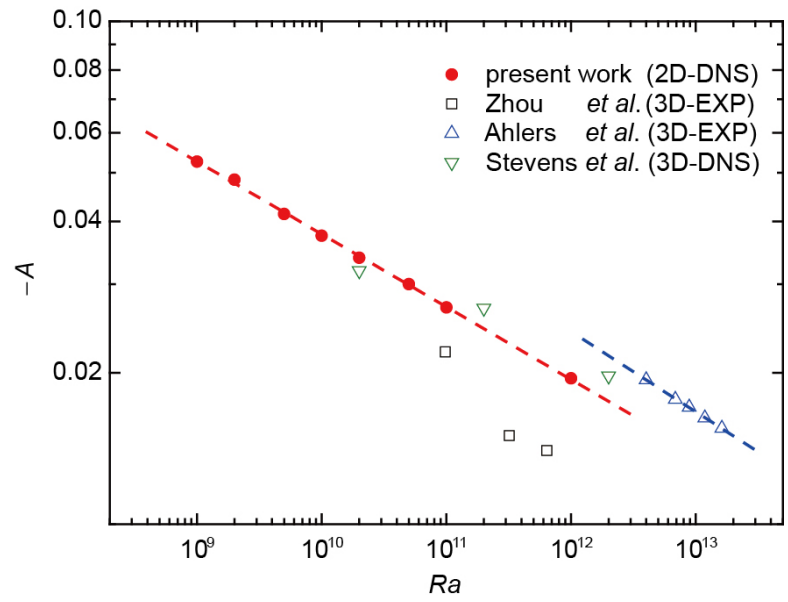

图 6 (网络版彩图)温度剖面对数律振幅 $-A$ 和 $R a$ 数的关系, 红色实圆圈表示本文的二维方腔数值模拟数据结果, 这些数 据结果由横向平均的平均场温度剖面得到; 黑色空方块表 示Zhou等人 ${ }^{[11]}$ 的三维实验数据结果, 是由轴向位置的温度 剖面得到; 蓝色空心的上三角表示Ahlers等人 ${ }^{[2]}$ 的三维实验 数据结果, 绿色空心的下三角表示Stevens等人 ${ }^{[12]}$ 的三维数 值模拟数据结果, 由径向位置 $(R-r) / L=0.0045$ 处的温度剖面 得到. 红色虚线为二维数值模拟数据的拟合线 $-A \sim R a^{-\eta}$, 得到 $\eta=0.145$, 蓝色虚线为三维实验数据的拟合线, 得到 $\eta=0.159$ Figure 6 (Color online) The log amplitude $-A$ as a function of $R a$. The two-dimension numerical results from horizontally averaged temperature profiles are indicated by the red dots. The three-dimension experimental results form Zhou et al. [11] measured along the vertical center axis are indicated by the open squares. The three-dimension experimental results form Ahlers et al. [2] and three-dimension numerical results from Stevens et al. [12], which data are for a radial position $(R-r) / L=0.0045$, are indicated by the open blue upward-pointing triangles and the open downward-pointing triangles, respectively. The red dashed line is fit of the function $-A \sim R a^{-\eta}$ to the two-dimension numerical data yielded $\eta=0.145$, while the blue dashed line to the three-dimension experimental data yielded $\eta=0.159$
度剖面对数律的研究有对数律振幅 $-A$ 随 $R a$ 数的变化 规律和随空间位置的变化规律等. Ahlers等人 ${ }^{[2]}$ 得到 对数律振幅 $-A$ 和 $R a$ 的关系为 $\eta=0.159$, 认为温度剖面 对数律可能跟焓扩散有关, 羽流携带的焓从边界层 进入到主流区. 在本文中, 羽流集中的区域有温度剖 面对数律存在, 横向平均得到的温度剖面也有对数 律存在. 随着 $R a$ 数的增加, 横向平均的温度剖面对数 律振幅 $-A$ 会变小, 得到对数律振幅 $-A$ 和 $R a$ 的关系为 $\eta=0.145$. 温度剖面对数律的物理本质还有待进一步 研究.

\section{4 结论}

湍流热对流研究在当今物理学和流体力学中极 具重要性, 近年来, 对温度剖面对数律的研究是热门 研究课题. DNS数值模拟研究是湍流热对流研究的三 大手段之一. 本文利用并行直接数值模拟计算了二维 方腔 RB热对流, 计算得到的湍流 RB热对流传热 $N u$ 数 与其他研究者的计算结果基本一致, 表明本文的计算 结果是合理可靠的. 通过对 $P r=4.3,10^{9} \leq R a \leq 10^{12}$ 的二维 方腔的温度剖面特性研究, 得到以下结论：

(1) 将边界层沿横向分为三个区域, 即羽流发射 区、冲击区和大尺度环流剪切区. 在发射区和冲击 区, 速度主要是垂向的, 而在剪切区, 速度主要是水平 方向的. 当 $R a=10^{10}$ 时, 发射区为 $0.2<x<0.4$, 冲击区为 $0.7<x<0.8$, 大尺度环流剪切区为 $0.4<x<0.7$.

(2) 当 $R a=10^{10}$ 时, 选取三个典型的横向位置, 羽流 发射区 $x=0.3$ 、冲击区 $x=0.7$ 和大尺度环流剪切区 $x=0.5$. 通过三个典型横向位置的温度剖面和横向平均的温 度剖面研究发现, 在半对数坐标下, 冲击区和大尺度 环流剪切区的温度剖面没有明显的对数律特征, 发射 区存在温度剖面对数律, 横向平均的温度剖面也存在 对数律.

(3) 对于不同 $R a$ 数, 在半对数坐标下, 对横向平均 的温度剖面拟合, 发现随着 $R a$ 数的增加, 温度剖面对 数律区域变宽. 通过对数律关系 $\left\langle\theta>_{\mathrm{t}}=A \times \log (y)+B\right.$, 得 到不同 $R a$ 数温度剖面对数律振幅 $-A$. 随着 $R a$ 数的增 加, 横向平均的温度剖面对数律振幅 $-A$ 会变小. 在双 对数坐标下, 由二维方腔数值模拟数据得到对数律振 幅 $-A$ 和 $R a$ 数的关系为 $-A \sim R a^{-0.145}$ 与 Ahlers 等人的实验 结果基本一致. 


\title{
参考文献
}

1 Ahlers G, Grossmann S, Lohse D. Heat transfer and large scale dynamics in turbulent Rayleigh-Bénard convection. Rev Mod Phys, 2009, 81: 503-537, arXiv: 0811.0471

2 Ahlers G, Bodenschatz E, Funfschilling D, et al. Logarithmic temperature profiles in turbulent Rayleigh-Bénard convection. Phys Rev Lett, 2012, 109: 114501, arXiv: 1204.6465

3 Zhou Q, Xia K Q. Measured instantaneous viscous boundary layer in turbulent Rayleigh-Bénard convection. Phys Rev Lett, 2010, 104: 104301, arXiv: 0909.1629

4 Stevens R J A M, Zhou Q, Grossmann S, et al. Thermal boundary layer profiles in turbulent Rayleigh-Bénard convection in a cylindrical sample. Phys Rev E, 2012, 85: 027301, arXiv: 1110.6329

5 Grossmann S, Lohse D. Multiple scaling in the ultimate regime of thermal convection. Phys Fluids, 2011, 23: 045108

6 Ahlers G, Bodenschatz E, He X. Logarithmic temperature profiles of turbulent Rayleigh-Bénard convection in the classical and ultimate state for a Prandtl number of 0.8. J Fluid Mech, 2014, 758: 436-467, arXiv: 1404.3459

7 Van der Poel E P, Ostilla-Mónico R, Verzicco R, et al. Logarithmic mean temperature profiles and their connection to plume emissions in turbulent Rayleigh-Bénard convection. Phys Rev Lett, 2015, 115: 154501, arXiv: 1510.01568

8 Xu W, Bao Y. An efficient solution for 2D Rayleigh-Bénard convection using FFT (in Chinese). Acta Mech Sin, 2013 45: 666-671 [徐炜, 包芸. 利用FFT高效求解二维瑞利-贝纳德热对流. 力学学报, 2013, 45: 666-671]

9 Van der Poel E P, Stevens R J A M, Lohse D. Comparison between two- and three-dimensional Rayleigh-Bénard convection. J Fluid Mech, 2013, 736: $177-194$

10 Grossmann S, Lohse D. Logarithmic temperature profiles in the ultimate regime of thermal convection. Phys Fluids, 2012, 24: 125103, arXiv: 1208.2597

11 Zhou Q, Xia K Q. Thermal boundary layer structure in turbulent Rayleigh-Bénard convection in a rectangular cell. J Fluid Mech, 2013, 721: $199-224$

12 Stevens R J A M, Lohse D, Verzicco R. Prandtl and Rayleigh number dependence of heat transport in high Rayleigh number thermal convection. J Fluid Mech, 2011, 688: 31-43

\section{Logarithmic mean temperature profiles in turbulent Rayleigh-Bénard convection}

\author{
HUANG MaoJing \& BAO Yun* \\ Department of Applied Mechanics and Engineering, Sun Yat-Sen University, Guangzhou 510275, China
}

Results of two-dimensional turbulent Rayleigh-Bénard (RB) convection based on the parallel direct method of direct numerical simulation (PDM-DNS) in sample of aspect ratio $\Gamma=1$ up to Rayleigh number $R a=10^{12}$ are presented. Mean temperature field near the bottom of the sample for $R a=10^{10}$ and $P r=4.3$ is studied. The boundary layer of Rayleigh-Bénard convection can be divided horizontally into three regions, namely, ejecting region where thermal plumes are emitted, impacting region and large-scale circulation shearing region. The temperature profile is logarithmic in the ejecting region while the logarithmic behavior is not visible in the impacting region and the large-scale circulation shearing region. In addition, the horizontally averaged profile also reveals a logarithm. The horizontally averaged temperature varies as $A \times \log (y)+B$ with the distance $y$ from the bottom plate of the sample. The log amplitude $-A$ scales as $R a^{-0.145}$, in good agreement with the experiment.

Rayleigh-Bénard convection, turbulence, logarithmic temperature profile, PDM-DNS

PACS: 47.27.Te, 47.20.Bp, 47.11.-j

doi: $10.1360 /$ SSPMA2016-00427 